\title{
KONTRIBUSI TINGKAT PARTISIPASI SISWA PADA KEGIATAN KURIKULUM PENGEMBANGAN DIRI TERHADAP KESEGARAN JASMANI SISWA SMA NEGERI KOTA KENDARI
}

\author{
Oleh

\section{La Ode Maklum Sabrin} \\ Dosen Jurusan Pendidikan Jasmani FKIP Universitas Halu Oleo \\ Email: laodemaklumsabrin@yahoo.co.id
}

\begin{abstract}
Abstrak. Telah dilakukan penelitian Kontribusi Tingkat Partisipasi Siswa pada Kegiatan Kurikulum Pengembangan Diri Terhadap Kesegaran Jasmani Siswa SMA Negeri Kota Kendari. Penelitian ini bertujuan: (1) untuk mengetahui tingkat partisipasi siswa pada kegiatan kurikulum pengembangan diri siswa SMA Negeri Kota Kendari, (2) untuk mengetahui kesegaran jasmani siswa SMA Negeri Kota Kendari, (3) untuk mengetahui berapa besar kontribusi tingkat partisipasi siswa pada kegiatan kurikulum pengembangan diri terhadap kesegaran jasmani Siswa SMA Negeri Kota Kendari. Populasinya adalah siswa putra SMA Negeri Kota Kendari dengan sampel berjumlah 90 orang siswa teknik yang digunakan yaitu teknik area random sampling. Teknik analisis data yang digunakan adalah regresi. Berdasarkan hasil tersebut dapat disimpulkan bahwa: (1) tingkat partisipasi siswa pada kegiatan kurikulum pengembangan diri siswa SMA Negeri Kota Kendari dikategorikan kurang (2) kesegaran jasmani siswa SMA Negeri Kota Kendari dikategorikan sedang, (3) kontribusi tingkat partisipasi siswa pada kegiatan kurikulum pengembangan diri terhadap kesegaran jasmani siswa SMA Negeri Kota Kendari sebesar $28.0 \%$.
\end{abstract}

Kata Kunci: Tingkat partisipasi siswa, pengembangan diri, kesegaran jasmani.

\section{A. PENDAhuluan}

Dalam upaya untuk mengantisipasi perkembangan ilmu pengetahuan dan teknologi, berbagai upaya telah dilakukan oleh Departemen Pendidikan Nasional untuk memperbaiki mutu pendidikan Nasional. Menurut (UU RI No. 20 Tahun 2003) menyatakanbahwa: "Pendidikan Nasional berfungsi mengembangkan kemampuan dan membentuk watak serta peradaban bangsa yang bermartabat dalam rangka mencerdaskan kehidupan bangsa, bertujuan untuk berkembangnya potensi peserta didik agar menjadi manusia yang beriman dan bertaqwa kepada Tuhan Yang Maha Esa, berakhlak mulia, sehat, berilmu, cakap, kreatif, mandiri dan menjadi warga negara yang demokratis serta bertanggungjawab."
Undang-Undang tersebut memberikan isyarat bahwa pembangunan pendidikan nasional diarahkan pada pengembangan sumber daya manusia Indonesia yang memiliki kepribadian yang kuat, sehat jasmani dan rohani, memiliki ilmu pengetahuan, demokratis dan bertanggungjawab, yang dilandasi dengan keimanan dan ketaqwaan terhadap Tuhan Yang Maha Esa.Peraturan Mendiknas No. 22 tentang Standar Isi untuk Satuan Pendidikan Dasar dan Menengah dan Peraturan Mendiknas No. 23 tentang Standar Kompetensi Lulusan untuk Satuan Pendidikan Dasar dan Menengah. Untuk mengatur pelaksanaan peraturan tersebut pemerintah mengeluarkan pula Peraturan Mendiknas No. 24 tahun 2006.

Dari ketiga peraturan tersebut memuat beberapa hal penting diantaranya bahwa satuan 
pendidikan dasar dan menengah mengembangkan dan menetapkan Kurikulum Tingkat Satuan Pendidikan Dasar dan Menengah, yang kemudian dipopulerkan dengan istilah KTSP. Kurikulum tingkat satuan pendidikan (KTSP) adalah suatu ide tentang pengembangan kurikulum yang diletakkan pada posisi yang paling dekat dengan pembelajaran yakni sekolah dan satuan pendidikan. Kurikulum tingkat satuan pendidikan merupakan paradigma baru pengembangan kurikulum, yang memberikan otonomi luas pada setiap satuan pendidikan, dan pelibatan masyarakat dalam rangka mengefektifkan proses belajar mengajar di sekolah.

Di dalam KTSP, struktur kurikulum yang dikembangkan mencakup tiga komponen, yaitu: (1) Mata pelajaran; (2) Muatan lokal dan (3) Pengembangan diri. Komponen pengembangan diri merupakan komponen yang relatif baru dan berlaku untuk dikembangkan pada semua jenjang pendidikan. Menurut Sanjaya, (2010:159) menyatakan bahwa salah satu komponen utama kurikulum tingkat satuan pendidikan (KTSP) pada tingkat sekolah menengah atas (SMA) adalah struktur dan muatan kurikulum tingkat satuan pendidikan yang meliputi sejumlah mata pelajaran yang keluasan dan kedalamannya merupakan beban belajar bagi peserta didik, muatan lokal, dan kegiatan pengembangan diri pada satuan pendidikan.

Pelaksanaan kegiatan kurikulum pengembangan diri atau biasa dikenal dengan kegiatan ekstrakurikuler pada SMA Negeri Kota Kendari belum berjalan sesuai dengan apa yang diharapkan, ada beberapa hal yang disebabkan, antara lain: (1) siswa lebih cenderung mengikuti kegiatan pengembangan diriselain bidang olahraga, seperti: kepramukaan, seni, kegiatan band dan latihan dasar kepemimpinan, (2) siswa masih beranggapan bahwa kegiatan pengembangan diri tidak termasuk dalam mata pelajaran yang diwajibkan untuk diikuti, (3) tidak tersediahnya guru, pelatih atau pembimbing yang profesional pada bidang olahraga, (4) kesadaran siswa untuk melakukan aktifitas gerak masih kurang, (5) ketersediaan sarana maupun prasarana yang ada di sekolah masih kurang, sehingga siswa merasa tidak tertarik untuk melakukan kegiatan pengembangan diri. Siswa lebih banyak memilih jenis kegiatan pengembangan diri ataukegiatanekstrakurikuler yang tidak mengeluarkan banyak tenaga, karena menurut siswa tidak ada paksaan untuk menetapkan suatu kegiatan dan bukan suatu mata pelajaran yang diwajibkan untuk diikuti.

Pelaksanaan pendidikan jasmani di sekolah merupakan salah satu usaha untuk menanamkan kebiasaan hidup berolahraga, seperti melaksanakan kegiatan pengembangan diri, sehingga di dalam kehidupannya agar dapat tumbuh dan berkembang secara harmonis. Pengetahuan tentang jasmani yang sehat memungkinkan terjadi perubahan sikap dan perilaku ke arah kognitif, afektif, dan psikomotor yang sangat bermanfaat bagi siswa dalam melakukan aktifitasnya terutama dalam melaksanakan proses pembelajaran di sekolah sehingga dapat meningkatkan kesegaran jasmaninya.

Disadari bahwa untuk mencapai kesegaran jasmani yang lebih baik, dibutuhkan 
aktifitas olahraga secara teratur dan berkesinambungan termasuk kegiatan pengembangan diri di sekolah. Pelaksanaan pengembangan diri atau kegiatan ekstrakurikuler akan memberikan dampak yang positif terhadap respon-respon muscular terhadap siswa yang diekspresikan melalui kemampuan teknik gerakan sehingga akan meningkatkan kemampuan kardiovasculer.

Namun kenyataannya, dari beberapa hasil penelitian sebelumnya menunjukkan tingkat kesegaran jasmani siswa berada pada kategori yang kurang, hal tersebut bertolak belakang dengan hasil penilaian guru yang diberikan kepada siswa dalam proses belajar mengajar, seperti siswa mendapat nilai yang baik pada mata pelajaran pendidikan jasmani, olahraga dan kesehatan, tetapi kesegaran jasmaninya kurang. Masalah tersebut juga terjadi pada siswa SMA Negeri Kota Kendari. Kesegaran jasmani yang masih kurang disebabkan, karena: (1) keinginan siswa untuk melakukan aktifitas olahraga masih rendah, (2) kurang aktifnya siswa pada saat melakukan praktek mata pelajaran pendidikan jasmani, olahraga dan kesehatan yang diajarkan oleh guru, (3) kurangnya pemahaman siswa tentang manfaat akanpentingnya melakukan aktifitas gerak, (4) masih adanya siswa yang memiliki nilai akhir (rapor) yang tinggi sementara tidak sesuai kenyataan yang dilakukan oleh siswa dilapangan pada saat melakukan praktek olahraga.

Dengan terbatasnya sarana dan parasana dan tenaga guru pendidikan jasmani olahraga dankesehatanyang profesional yang ada di sekolah khususnya di SMA Kota
Kendari berdampak pada pelaksanaan kegiatan pengembangan diri ataukegiatanekstrakurikuler berjalan kurang efektif khususnya dalam melakukan kegiatan olahraga, sehingga berdampak pada pencapaian kesegaran jasmani siswa.

\section{B. METODE PENELITIAN}

\section{Jenis dan Lokasi Penelitian}

Penelitian ini digolongkan sebagai penelitian deskriptif yang bersifat regresi dan lokasi penelitian ini dilaksanakan pada siswa SMA Negeri Kota Kendari.

\section{Variabel Penelitian}

Variabel yang digunakan dalam penelitian ini adalah sebagai berikut:

1. Variabel Bebas (Independent) yaitu: Tingkat partisipasi siswa padakegiatan kurikulum pengembangan diri (X)

2. Variabel Terikat (dependent) yaitu: Kesegaran jasmani siswa (Y)

\section{Desain Penelitian}

Penelitian ini adalah merupakan jenis penelitian deskriptif dengan jenis analisis statistik bentuk analisis regresi, maka model desain penelitian yang digunakan dapat, sehingga dapat digambarkan sebagai berikut:

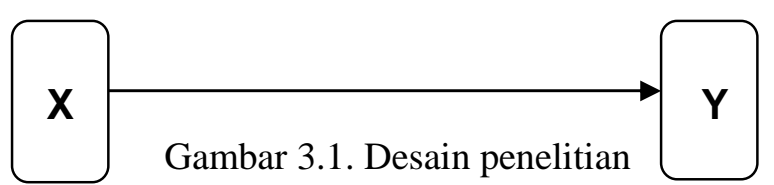

(Sugiyono, 2009:66)

\section{Definisi Operasional Variabel}

Komponen utama yang dimaksudkan dalam penelitian ini adalah: 
1. Partisipasi siswa pada kegiatan kurikulum pengembangan diri yang dimaksudkan dalam penelitian ini adalah kegiatan yang dilakukan secara sistematis dan terstruktur serta dapat memberikan kesempatan kepada peserta didik untuk mengembangkan dan mengekspresikan diri sesuai dengan bakat yang dimilikinya dalam bidang pendidikan jasmani dan olahraga.

2. Kesegaran jasmani siswa yang dimaksudkan dalam penelitian ini adalah jumlah skor keseluruhan yang diperoleh siswa yang meliputi: lari 60 meter, bergantung angkat tubuh, baring duduk 60 detik, loncat tegak, dan lari 1200 meter yang dikeluarkan oleh pusat pengembangan kualitas jasmani tahun 2010.

\section{Populasi dan Sampel}

Populasi dalam penelitian ini adalah seluruh siswa SMA Negeri Kota Kendari yang berjumlah 6949 orang siswa. Karena begitu banyaknya populasi yang ada di Kota Kendari, maka peneliti mengadakan reduksi dari jumlah populasi yang ada sedangkan sampel sebanyak 90 orang untuk tiga sekolah yang akan dijadikan sampel. Untuk mendapatkan sampel sebanyak 90 orang, maka peneliti menentukan jumlah sekolah terlebih dahulu dengan teknik area random sampling (sampling daerah).

\section{Instrumen Penelitian}

Penelitian ini menggunakan instrumen kuisioner atau angket dan tes kesegaran jasmani Indonesia (TKJI). Angket /kuisioner digunakan untuk mengetahui tingkat partisipasi siswa pada kegiatan kurikulum pengembangan diri serta tes kesegaran jasmani Indonesia yang bertujuan untuk mengetahui tingkat kesegaran jasmani siswa.

\section{Teknik dan Prosedur Pengumpulan Data}

a. Angket/kuesioner,

Angket yang dimaksudkan dalam penelitian ini adalah angket untuk mengetahui tingkat partisipasi siswa pada kegiatan kurikulum pengembangan diri yang ada di sekolah

b. Tes kesegaran jasmani Indonesia, meliputi:

1. Lari cepat 60 meter.

Tujuan: untuk mengukur kecepatan.

Alat/fasilitas: Lintasan lurus, datar, rata, berjarak 60 meter, dan masih mempunyai lintasan lanjutan, bendera start, sumpritan/Peluit, tiang pancang, stopwatch, serbuk kapur, dan alat tulis. Petugas tes: petugas keberangkatan, pengukur waktu merangkap pencatat hasil.

Kegiatan:

1. Sikap permulaan: peserta berdiri dibelakang garis start;

2. Gerakan pada aba-aba "Siap" peserta mengambil sikap start berdiri, siap 
untuk berlari; Pada aba-aba "Ya" peserta lari secepat mungkin menuju garis finish, menempuh jarak 60 meter;

3. Lari masih bisa diulang apabila: pelari mencuri start, tidak melewati garis finish, dan pelari terganggu dengan pelari lain;

4. Pengukuran waktu dilakukan mulai saat bendera diangkat sampai pelari tepat melintas garis finish.

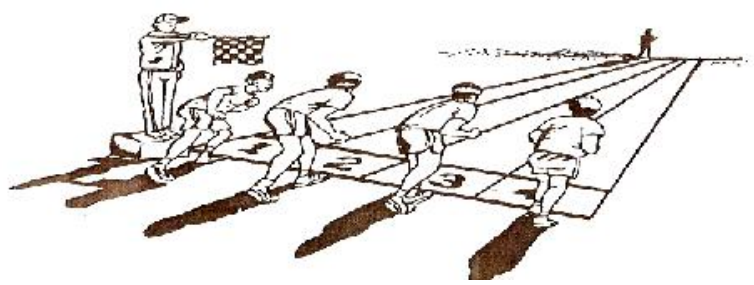

Gambar 1. Posisi start lari 60 meter (Sumber: TKJI: 2010:7)

Pencatat hasil:

1. Hasil yang dicatat adalah waktu yang dicapai oleh pelari untuk menempuh jarak 60 meter, dalam satuan waktu detik;

2. Waktu dicatat satu angka di belakang koma.

2. Bergantung angkat tubuh 60 detik

Tujuan: Untuk mengukur kekuatan dan ketahanan otot lengan dan otot bahu.

Alat/fasilitas: Lantai rata, palang tunggal, stopwatch, serbuk kapur, dan alat tulis.

Petugas tes: Pengamat waktu, penghitung gerakan merangkap pencatat hasil.

Kegiatan:

1. Sikap permulaan: peserta berdiri di bawah palang tunggal. Kedua tangan berpegangan pada palang tunggal selebar bahu. Pegangan telapak tangan menghadap ke arah letak kepala;

2. Gerakan mengangkat tubuh dengan membengkokkan kedua tangan, sehingga dagu menyentuh atau berada diatas palang tunggal kemudian kembali ke sikap permulaan. Gerakan ini dihitung satu kali;

3. Selama melakukan gerakan, mulai dari kepala sampai ujung kaki tetap lurus;

4. Gerakan ini dilakukan berulang-ulang, tanpa istrahat, sebanyak mungkin selama 60 detik;

5. Angkatan dianggap gagal atau tidak dihitung apabila pada waktu mengangkat badan peserta melakukan gerakan mengayun, dagu tidak menyentuh palang tunggal, dan pada waktukembali ke sikap permulaan kedua lengan tidak lurus.

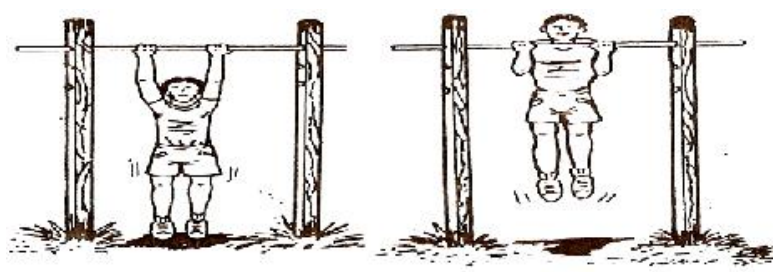

Gambar 2. Sikap gantung angkat tubuh (Sumber: TKJI: 2010:9)

Penilaian: Gerakan yang dicatat adalah jumlah gerakan yang dilakukan dengan sempurna, tanpa istirahat selama 60 detik.

3. Tes baring duduk 60 detik Tujuan: untuk mengukur kekuatan dan ketahanan otot perut. 
Alat/fasilitas: Lapangan yang rata, stopwatch, formulis tes dan alat tulis.

Petugas tes: Pengamat waktu, penghitung gerakan merangkap pencatat hasil.

Kegiatan:

1. Sikap permulaan: berbaring telentang di lantai, kedua lutut ditekuk dengan sudut \pm 90 derajat, kedua jari-jari dari kedua telapak tangan saling berselang seling diletakkan dibelakang kepala;

2. Petugas menekan kedua pergelangan kaki, agar kaki tidak terangkat;

3. Gerakan aba-aba "ya" peserta mengambil sikap duduk sampai kedua sikunya menyentuh kedua paha, kemudian kembali ke sikap permulaan;

4. Gerakan tersebut dilakukan berulangulang dengan cepat tanpa istrahat, 60 detik;

5. Gerakan tidak dihitung, jika tangan terlepas sehingga jari-jarinya tidak terjalin lagi, kedua siku tidak menyentuh paha, dan mempergunakan sikunya untuk membantu menolak tubuh.

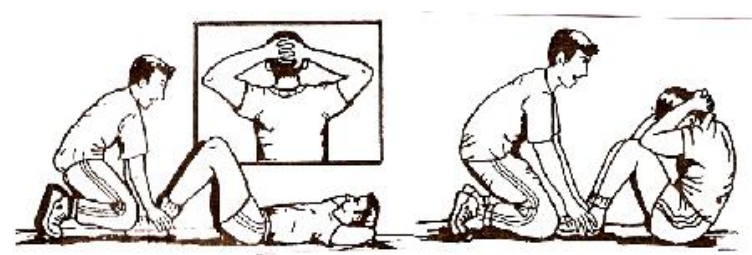

Gambar 3. Sikap baring duduk (Sumber: TKJI: 2010:14)
Penilaian: Hasil yang dihitung dan dicatat adalah jumlah gerakan baring duduk selama waktu 60 detik yang dapat dilakukan dengan sempurna.

\section{Loncat tegak}

Tujuan: untuk mengukur daya ledak atau tenaga eksplosif.

Alat/fasilitas: Papan berskala centimeter, berukuran $30 \times 150 \mathrm{~cm}$, dipasang pada dinding yang rata. Jarak antara lantai dengan skala 0 (nol) pada skala yaitu $150 \mathrm{~cm}$, serbuk kapur, formulir tes dan alat tulis.

Petugas tes: Pengamat dan pencatat hasil.

Kegiatan:

(1) Sikap permulaan terlebih dahulu ujung jari tangan peserta diolesiserbuk kapur;

(2) Peserta berdiri tegak dekat dinding, kaki rapat, papan berskala berada di samping kiri atau kanan. Kemudian tangan yang dekat dinding diangkat lurus ke atas, telapak tangan ditempelkan pada papan berskala, sehingga meninggalkan bekas raihan jarinya;

(3) Peserta mengambil gerakan awalan dengan sikap menekukkan lutut dan kedua lengan mengayun kebelakang, kemudianpeserta meloncat setinggi mungkin dengan menepuk papan dengan ujung jari yang terdekat sehingga 
menimbulkan bekas, dengan melakukan loncatan sebanyak 3 kali tanpa istrahat.
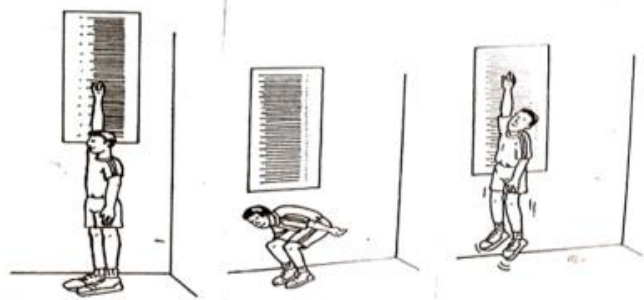

Gambar 4. Sikap loncat tegak

(Sumber: TKJI: 2010:19)

Penilaian: Raihan tegak dicatat, dan ketiga raihan loncatan, raihan loncatan tertinggi dikurangi raihan tegak.

5. Lari 1200 meter

Tujuan: Untuk mengukur daya tahan jantung, peredaran darah dan pernapasan.

Alat/fasilitas: Lintasan lari 1200 meter, stopwatch, bendera start, sumpritan, tiang pancang, formulir tes dan alat tulis. Petugas tes : Petugas keberangkatan, pengukur waktu, pencatat hasil, dan pembantu umum

Kegiatan:

1. Sikap permulaan: peserta berdiri di belakang garis start;

2. Gerakan pada aba-aba "siap" peserta berdiri mengambil sikap start berdiri, siap untuk berlari;

3. Pada aba-aba "ya" peserta lari menuju garis finish, menempuh jarak 1200 meter;
4. Lari diulang bila ada pelari yang mencuri start dan tidak melewati garis finish.

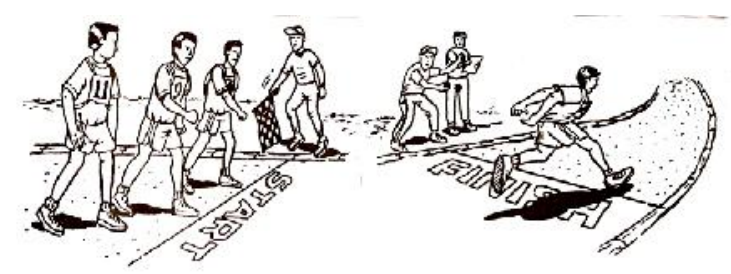

Gambar 3.6. Posisi start dan finish lari 1200 meter (Sumber: TKJI: 2010:21)

\section{Teknik Analisis Data}

1. Analisis data secara deskriptif dimaksudkan untuk mendapatkan gambaran umum tentang data apa adanya yang meliputi data minimum dan maksimum, rata-rata, dan standar deviasi;

2. Analisis secara inferensial digunakan untuk menguji hipotesis penelitian dengan menggunakan uji regresi dengan bantuan komputer SPSS dengan taraf signifikan $95 \%$ atau $\alpha=0,05$. 


\section{HASIL PENELITIAN DAN PEMBAHASAN}

Dari hasil uji Kolmogorov-Smirnov Test yang di lakukan, diperoleh hasil berikut:

Tabel 1.
Hasil uji normalitas data partisipasi siswa pada kegiatan kurikulum pengembangan diri siswa SMA Negeri Kota Kendari.

\begin{tabular}{lllll}
\hline Variabel & $\mathrm{K}-\mathrm{SZ}$ & $\mathrm{P}$ & $\alpha$ & Ket. \\
\hline Partisipasi siswa & 0,959 & 0,507 & 0,05 & Normal \\
\hline
\end{tabular}

Data partisipasi siswa pada kegiatan berdistribusi normal, sebagaimana terlihat kurikulum pengembangan diri siswa SMA pada tabel 2 berikut ini;

Negeri Kota Kendari yang diperoleh

Tabel 2. Hasil uji normalitas data kesegaran jasmani siswa SMA Negeri Kota Kendari

\begin{tabular}{ccccc}
\hline Variabel & K $-\mathrm{SZ}$ & $\mathrm{P}$ & $\alpha$ & Ket. \\
\hline TKJI & 0,834 & 0,490 & 0,05 & Normal \\
\hline
\end{tabular}

Sesuai dengan perhitungan statistik pengembangan diri siswa SMA Negeri ditemukan bahwa gambaran partisipasi Kota Kendari adalah sebagai berikut: siswa pada kegiatan kurikulum

Tabel 3. Hasil analisis data partisipasi siswa pada kegiatan kurikulum pengembangan diri siswa SMA Negeri Kota Kendari

\begin{tabular}{cccccccc}
\hline Variabel & $\mathrm{N}$ & $\Sigma \mathrm{x}$ & $\mu$ & $\mathrm{Sd}$ & Range & Min. & Max. \\
\hline Partisipasi siswa & 90 & 7279.00 & 64.487 & 5.15998 & 33.00 & 58.00 & 91.00
\end{tabular}

Sesuai dengan perhitungan statistik kurikulum pengembangan diri siswa SMA ditemukan bahwa gambaran tingkat Negeri Kota Kendari sebagai berikut: kesegaran jasmani siswa pada kegiatan

Tabel 4. Hasil analisis data kesegaran jasmani siswa SMA Negeri Kota Kendari.

\begin{tabular}{cccccccc}
\hline Variabel & $\mathrm{N}$ & $\Sigma \mathrm{x}$ & $\mu$ & $\mathrm{Sd}$ & Range & Min. & Max. \\
\hline TKJI & 90 & 1375.00 & 15.2778 & 2.98320 & 12.00 & 10.00 & 22.00 \\
\hline
\end{tabular}

Sesuai dengan perhitungan statistik ditemukan bahwa kontribusi tingkat partisipasi siswa pada kegiatan kurikulum pengembangan diri terhadap kesegaran 
jasmani siswa SMA Negeri Kota Kendari sebagai berikut:

Tabel 5. Hasil analisis regresi partisipasi siswa pada kegiatan kurikulum pengembangan diri terhadap kesegaran jasmani siswa SMA Negeri Kota Kendari

\begin{tabular}{lllllll}
\hline Hipotesis & N & R & Rs & F & t & Sig \\
\hline Kontribusi partisipasi siswa & & & & & & \\
pada kegiatan kurikulum & & & & & & \\
pengembangan diri terhadap & 90 & 0,383 & 0,280 & 7,676 & 0,924 & 0,007 \\
kesegaran jasmani siswa & & & & & & \\
SMA Negeri Kota Kendari & & & & & & \\
\hline
\end{tabular}

\section{PEMBAHASAN HASIL PENELITIAN}

Hasil analisis data telah dikemukakan bahwa hipotesis yang diajukan diterima dan menunjukkan ada kontribusi. Dari hasil tes partisipasi siswa pada kegiatan kurikulum pengembangan diri terhadap kesegaran jasmani siswa SMA Negeri Kota Kendari pada penelitian ini relevan dengan kerangka berpikir yang telah dikembangkan berdasarkan teori-teori yang mendukung penelitian. Untuk lebih jelasnya akan dibahas tentang hipotesis yang telah dirumuskan sebelumnya tentang kontribusi partisipasi siswa pada kegiatan kurikulum pengembangan diri terhadap kesegaran jasmani siswa SMA Negeri Kota Kendari.

Ada kontribusi partisipasi siswa pada kegiatan kurikulum pengembangan diri terhadap kesegaran jasmani siswa SMA Negeri Kota Kendari sebesar 28,0\% atau sebesar 0,280 dapat disimpulkan bahwa tingkat partisipasi siswa pada kegiatan pengembangan diri terhadap kesegaran jasmani siswa SMA Negeri Kota Kendari kategori rendah. Terbukti dari hasil analisis diperoleh nilai regresi observasi $\left(R_{O}\right)$ 0,383 dengan nilai koefesien determinasi 0,280. Hasil ini menunjukkan bahwa partisipasi siswa pada kegiatan kurikulum pengembangan diri terhadap kesegaran jasmani siswa SMA Negeri Kota Kendari memiliki kontribusi terhadap kesegaran jasmani siswa SMA Negeri Kota Kendari.

Hipotesis yang menyatakan bahwa “ ada kontribusi partisipasi siswa pada kegiatan kurikulum pengembangan diri terhadap kesegaran jasmani siswa SMA Negeri Kota Kendari” telah diterima. Penerimaan hipotesis tersebut mengartikan bahwa variabel partisipasi siswa mempunyai kontribusi sebesar 28,0\% terhadap peningkatan kesegaran jasmani siswa SMA Negeri Kota Kendari. Partisipasi siswa pada kegiatan kurikulum pengembangan diri sebesar $28,0 \%$ atau dikategorikan rendah, hal tersebut disebabkan karena: (1) siswa lebih cenderung memilih kegiatan 
pengembangan diri atau kegiatan ekstarkueikuler selain bidang olahraga seperti kegiatan kepramukaan, seni, dengan alasan bahwa siswa diberi kebebasan untuk memilih tanpa ada paksaan, (2) kegiatan pengembangan diri/ekstrakurikuler pada SMA Negeri Kota Kendari dimonopoli oleh kegiatan studi lapangan, seperti : penyuluhan tentang, narkoba, kenakalan remaja, kegiatan seni. Sehingga cenderung siswa tidak mempunyai waktu untuk melakukan kegiatan fisik, (3) kurangnya pemahaman siswa tentang pentingnya melakukan aktifitas gerak tubuh, (4) siswa lebih cenderung mengikuti kegiatan pengembangan diri dalam bentuk kegiatan ekstrakurikuler yang tidak melibatkan aktifitas fisik, (5) sarana dan prasarana yang kurang mendukung, menyebabkan siswa terkadang malas untuk melakukan aktifitas jasmani seperti melaksanakan kegiatan kurikulum pengembangan diri dalam bidang olahraga.

\section{KESIMPULAN}

Kesimpulkan dari hasil penelitian ini adalah sebagai berikut:

1. Partisipasi siswa pada kegiatan kurikulum pengembangan diri siswa SMA Negeri Kota Kendari dikategorikankurang.

2. Kesegaran jasmani siswa SMA Negeri Kota Kendari dikategorikan sedang.
3. Kontribusi tingkat partisipasi siswa pada kegiatan kurikulum pengembangan diri terhadap kesegaran jasmani siswa SMA Negeri Kota Kendari sebesar $28.0 \%$. Maka dapat dikatakan bahwa dengan kontribusi sebesar $28 \%$ tingkat partisipasi pada kegiatan kurikulum pengembangan diri terhadap kesegaran jasmani siswa SMAN Kota Kendari dikategorikan rendah.

\section{DAFTAR PUSTAKA}

Halim, Ichsan, Nur. 2004. Tes dan Pengukuran Kesegaran Jasmani. UNM FIK. Makassar.

Kementerian Pendidikan Nasional Pusat Pengembangan Kualitas Jasmani. 2010.Tes kesegaran Jasmani Indonesia. Jakarta.

Peraturan Pemerintah RI. No. 19 tahun 2005 tentang Standar Nasional Pendidikan.

Peraturan Mendiknas No. 22 tentang Standar Isi untuk Satuan Pendidikan Dasardan Menengah.

Peraturan Mendiknas No. 23 tentang Standar Kompetensi Lulusan untuk Satuan Pendidikan Dasar dan Menengah.

Pusat Kesegaran Jasmani dan Rekreasi. 1976. Hasil Lokakarya Tes Kemampuan Gerak Dasar dan Tes Kesegaran Jasmani Indonesia; Bandung.

Sugiyono. 2009. Metode Penelitian Pendidikan (Pendekatan Kuantitatif, Kualitatif, dan $R \& D)$. Alfabeta: Bandung.

Undang-Undang Sistem Pendidikan Nasional (Sisdiknas) RI. No. 20 tahun 2003. 